\title{
PERBEDAAN EFEK PEMBERIAN TOPIKAL GEL LIDAH BUAYA (Aloe vera L.) DENGAN SOLUSIO POVIDONE IODINE TERHADAP PENYEMBUHAN LUKA SAYAT PADA KULIT MENCIT (Mus musculus)
}

\author{
Nur Atik, Januarsih Iwan A. R. \\ Bagian Histologi, Fakultas Kedokteran Universitas Padjadjaran Bandung
}

\begin{abstract}
ABSTRAK
Penyembuhan luka yang normal merupakan suatu proses kompleks dan dinamis. Proses penyembuhan dapat dibantu baik dengan pengobatan secara kimiawi maupun alami. Pengobatan kimiawi biasanya menggunakan povidone iodine sedangkan salah satu cara alami dengan pemberian topikal gel lidah buaya (Aloe vera L.) yang diduga dapat mempercepat proses penyembuhan luka. Tujuan penelitian ini untuk mengetahui perbedaan penyembuhan luka sayat yang diberikan topikal gel lidah buaya dengan povidone iodine pada kulit mencit. Penelitian ini menggunakan 18 mencit (Mus musculus) yang terbagi dalam 3 kelompok, yaitu kelompok luka sayat (kontrol), kelompok luka sayat - lidah buaya, dan kelompok luka sayat povidone iodine. Setiap kelompok dibuat full-thickness skin wound di punggung mencit. Luka pada grup kontrol tidak diberikan perlakuan, sementara gel lidah buaya diberikan secara topikal sebanyak 2 kali/hari pada grup kedua, dan solusio povidone iodine diberikan sebanyak 2 kali/hari pada grup ketiga. Pada hari kelima semua mencit dikorbankan untuk dievaluasi perubahan histologik dan ekspresi vascular endothelial growth factor A (VEGF-A). Data diperoleh melalui pengamatan mikroskopik terhadap jaringan kulit yang terluka, dengan parameter tebal epitel, jumlah rata-rata sel fibroblas, pembuluh darah dan ekspresi VEGF A, kemudian dianalisis statistik menggunakan independent samples $T$ test, Analisis of variant (ANOVA) dan Chi square. Dari hasil penelitian didapatkan tebal epitel, jumlah rata-rata fibroblas, pembuluh darah, dan ekspresi VEGF A pada kelompok luka sayat -lidah buaya lebih tebal dan lebih banyak jika dibandingkan dengan kelompok povidone iodine. Melalui uji statistik dapat diketahui adanya perbedaan yang bermakna $(p<0,05)$ tebal epitel, jumlah rata-rata sel fibroblas; pembuluh darah dan ekspresi VEGF A pada kedua kelompok dengan taraf kepercayaan 95\%. Hal ini menandakan bahwa pemberian topikal gel lidah buaya pada luka sayat kulit mencit sebanyak dua kali sehari lebih baik daripada pemberian solusio povidone iodine dilihat dari parameter tebal epitel, jumlah rata-rata fibroblas, pembuluh darah, dan ekspresi VEGF A.
\end{abstract}

Kata kunci: Lidah buaya (Aloe vera L.), solusio povidone iodine, penyembuhan luka sayat, pemberian topikal

\section{THE DIFFERENCES BETWEEN TOPICAL APLICATION OF THE ALOE VERA GEL WITH THE POVIDONE IODINE SOLUTIO FOR SKIN WOUND HEALING IN MICE (Mus Musculus)}

\begin{abstract}
Normal wound healing is a complex and dynamic process. Wound healing process can accelerate, with chemical treatment or natural. The chemical treatment often used in healing process is povidone iodine. For natural treatment, topical application of Aloe vera gel may accelerate the full-thickness wound healing process. The purpose of this research was to evaluate the differences between topical application of povidone iodine and Aloe vera gel for skin wound healing in mice. This study used 18 mice that were divided into three groups. First group was the wounded (control) group, the second group was wounded - Aloe vera group, the third group was wounded - povidone iodine group. Full-thickness skin wound were created on the dorsal area of mice in each group. The control group were not given anything, while the second group were given Aloe vera gel twice a day, and the third group were given povidone iodine solution twice a day. At the fifth day, all mice were sacrificed for histologic evaluation and VEGF A expression. Data was obtained by microscopic observation of the wounded skin, based on quantitative parameter: epithelial thickness, total fibroblast, total blood vessels, and VEGF A expression. Then the data was statistically analyzed by using independent samples T test, ANOVA, and Chi square. The result demonstrated that the sum of epithelial thickness, fibroblast, blood vessels, and VEGF A expression in the Aloe vera group is higher than in povidone iodine group.
\end{abstract}

\footnotetext{
Alamat Korespondensi

dr. Nur Atik

Bagian Histologi Fakultas Kedokteran Unpad

JI. Raya Bandung Sumedang Km.21 Jatinangor- Sumedang 45363

Telp 08562271919, Email: aa_tilla@yahoo.com
} 
Statistic evaluation showed that there were significant differences between the two groups $(p<0.05)$, with $95 \%$ confidence interval. Based on this result, it can be concluded that the topical administration of Aloe vera gel twice a day is better than povidone iodine with parameter epithelial thickness, total fibroblass, total blood vessels and VEGF A expression.

Key words: Aloe vera, povidone iodine solution, lacerating wound healing, topical application

\section{PENDAHULUAN}

Luka merupakan kasus cedera yang sering dialami oleh setiap manusia. Luka itu sendiri didefinisikan sebagai hilangnya integritas epitelial dari kulit. ${ }^{1}$ Organ ini berperan sangat penting dalam kehidupan manusia, antara lain dengan mengatur keseimbangan air serta elektrolit, termoregulasi, dan berfungsi sebagai barier terhadap lingkungan luar termasuk mikroorganisme. ${ }^{2}$ Saat barier ini rusak karena berbagai penyebab seperti ulkus, luka bakar, trauma, atau neoplasma maka kulit tidak dapat melaksanakan fungsinya secara adekuat. Oleh karena itu sangat penting untuk mengembalikan integritasnya sesegera mungkin. ${ }^{1}$

Penyembuhan luka yang normal merupakan suatu proses yang kompleks dan dinamis, tetapi mempunyai suatu pola yang dapat diprediksi. Proses penyembuhan luka dapat dibagi menjadi tiga fase pokok, yaitu : 1) hemostasis dan inflamasi, 2) proliferasi, 3) maturasi dan remodelling. Fase-fase ini terjadi saling bertindihan (overlapping), dan berlangsung sejak terjadinya luka, sampai tercapainya resolusi luka. ${ }^{1,3}$

Povidone iodine merupakan salah satu pengobatan luka secara kimiawi yang sering kali digunakan dalam penyembuhan luka. Povidone iodine memiliki efek antimikroba, menciptakan lingkungan lembab, dan dapat menginduksi angiogenesis. Obat ini juga dilaporkan dapat mencegah inflamasi namun povidone iodine $10 \%$ dikatakan pula memiliki efek menghambat pertumbuhan fibroblas pada percobaan kultur sel secara in vitro. ${ }^{4,5}$

Lidah buaya (Aloe vera L.) merupakan tumbuhan yang tidak asing lagi bagi masyarakat Indonesia. Di beberapa negara, lidah buaya seringkali digunakan sebagai langkah pertolongan pertama pada bagian tubuh yang terluka (luka sayat maupun luka bakar). Lidah buaya mengandung banyak zat-zat aktif yang sangat bermanfaat dalam mempercepat penyembuhan luka karena mengandung antara lain glukomanan, lignin, vitamin A, vitamin C, enzim-enzim, serta asam amino yang sangat penting untuk regenerasi sel-sel. Lidah buaya menstimulasi faktor pertumbuhan epidermis, meningkatkan fungsi fibroblas, dan pembentukan pembuluh darah baru sehingga dapat mempercepat penyembuhan dan penutupan luka. . $^{6-8}$

Untuk itu dilakukan penelitian yang bertujuan untuk mengetahui perbedaan pembe- rian topikal gel lidah buaya (Aloe vera L.) dengan solusio povidone iodine terhadap penyembuhan luka sayat pada kulit mencit (Mus musculus).

\section{METODE}

Penelitian ini merupakan percobaan eksperimental menggunakan hewan coba berupa 18 ekor mencit (Mus musculus) betina galur Swiss Webster dengan berat antara 20-25 gram, diperoleh dari Bagian Biologi Institut Teknologi Bandung. Hewan coba dibagi menjadi tiga kelompok perlakuan, yang masing-masing berjumlah enam ekor.

Variabel-variabel yang digunakan terdiri atas:

Variabel Bebas / Independen (Topikal gel lidah buaya dan povidone iodine 10\%), variabel terikat/dependen (tebal epitel, jumlah fibroblas, jumlah pembuluh darah, dan distribusi vascular endothelial growth factor $A$ \{VEGF-A\}), variabel terkendali (strain/galur mencit, jenis kelamin, berat badan, umur, makanan, dan minuman).

\section{Prosedur Penelitian}

Masing-masing kelompok mencit mendapat perlakuan full-thickness skin wound dengan gunting bedah yang sebelumnya diberikan anestesi lokal agar tidak menyakiti hewan coba. Masing-masing kelompok diberi perlakuan sebagai berikut: 1) kelompok luka sayat (enam ekor), pada hari kelima, semua mencit dikorbankan dan diambil jaringan kulit yang terluka, lalu dibuat sediaan preparat (untuk melihat epitel dan pembuluh darah baru dengan pewarnaan hematoksilin-eosin, fibroblas dengan pewarnaan toluidine - blue, dan pewarnaan imunohistokimia untuk melihat ekspresi VEGF A), 2) Kelompok Luka Sayat yang diberi gel lidah buaya (enam ekor), pemberian gel lidah buaya secara topikal sebanyak 2 kali sehari selama 5 hari. Pada hari kelima semua mencit dikorbankan dan diambil jaringan kulit yang terluka, lalu dibuat sediaan preparat histologis (untuk melihat epitel dan pembuluh darah baru dengan pewarnaan hematoksilin-eosin, fibroblas dengan pewarnaan toluidine - blue, dan pewarnaan Imunohistokimia untuk melihat ekspresi VEGF A), 3) kelompok Luka Sayat yang diberi povidone iodine (enam ekor), pemberian povidone iodine $10 \%$ secara topikal sebanyak 2 kali sehari selama 5 hari. Pada hari kelima semua mencit dikorbankan dan diambil jaringan kulit yang terluka, lalu dibuat sediaan preparat 
darah baru dengan pewarnaan hematoksilin- eosin, fibroblas dengan pewarnaan toluidine- blue, dan pewarnaan imunohistokimia untuk melihat ekspresi VEGF A).

\section{Pengamatan Histologis Secara Kuantitatif}

Data penelitian diperoleh melalui pengamatan secara mikroskopis terhadap jaringan kulit mencit yang sedang dalam proses penyembuhan. Pengamatan mikroskopis ini dilakukan secara kuantitatif dengan mengambil tiga parameter yaitu tebal pertumbuhan epitel, jumlah fibroblas dan jumlah pembuluh darah pada kulit yang terluka. Tebal pertumbuhan epitel diukur mulai dari dermis sampai ujung epitel yang tumbuh dengan menggunakan microruler pada lensa okuler mikroskop dengan skala 1 : 1.000 dengan pembesaran 400x, sementara jumlah fibroblas dan pembuluh darah pada kulit yang terluka dihitung dengan pembesaran 400x.

\section{Pengamatan VEGF A dengan Pewarnaan Imunohistokimia Secara Kualitatif}

Setelah jaringan kulit diwarnai dengan pewarnaan imunohistokimia (Novocastra $\left({ }^{\circ}\right.$ 1:50), maka di sekitar daerah dermis jaringan luka dilakukan identifikasi VEGF A dan kemudian dinilai intensitas dan kuantitas VEGF A untuk dibandingkan antara kelompok kontrol, lidah buaya dan povidone iodine. Penilaian secara kualitatif dengan cara membandingkan ekspresi warna VEGF A yang dibuat dengan kontrol positif kuat yang telah dibuat sebagai standar. Sedangkan untuk penilaian kuantitatif dengan cara melihat distribusi VEGF A yang terwarnai.

\section{Metode Penarikan Sampel}

Keempat parameter tersebut diukur dan dihitung dari setiap sediaan per lapang pandang sehingga didapat 18 nilai rata-rata tebal epitel, jumlah fibroblas, jumlah pembuluh darah, serta kualitas VEGF A per kelompok. Untuk menjaga objektivitas hasil penelitian, peneliti menggunakan single blind method.

\section{Analisis Data}

Untuk menganalisis perbedaan percepatan proses penyembuhan luka kelompok povidone iodine dengan kelompok kontrol dan kelompok gel lidah buaya dengan kontrol menggunakan independent $t$-test bila data berdistribusi normal (uji parametrik) dan menggunakan normal (uji nonparametrik). Sedangkan untuk menganalisis perbedaan antara kelompok kontrol, lidah buaya dan povidone iodine dengan menggunakan uji ANOVA bila data berdistribusi normal, sedangkan bila data tidak berdistribusi normal maka digunakan uji Kruskal-Wallis. Pada penelitian ini juga dilakukan uji statistik Chi square untuk menentukan adanya perbedaan ekspresi VEGF A pada masing-masing perlakuan.

\section{HASIL}

Setelah dilakukan percobaan terhadap hewan coba, kemudian jaringan kulit dibuat sedian preparatnya. Preparat yang telah dibuat kemudian dinilai dengan melihat parameter tebal epitel, jumlah fibroblas, jumlah pembuluh darah, dan ekspresi VEGF A. Hasil masing-masing parameter kemudian dianalisis secara statistik.

\section{Tebal Epitel}

Rata-rata tebal epitel pada kelompok povidone iodine lebih besar dibanding kontrol, begitu pula pada kelompok lidah buaya yang terlihat lebih tebal dibanding kontrol bahkan lebih tebal dari perlakuan povidine iodine (Gambar $1 a, b$ dan 3). Hasil analysis of varians (ANOVA) menunjukkan adanya perbedaan tebal epitel secara bermakna antara kelompok lidah buaya, povidone iodine dan kontrol seperti terlihat pada Tabel 1.

\section{Jumlah Fibroblas}

Pada penelitian ini didapatkan rata-rata jumlah fibroblas pada kelompok lidah buaya terlihat lebih banyak dibanding kontrol dan kelompok povidone iodine sedangkan pada kelompok povidone iodine jumlah fibroblas lebih sedikit dibanding kontrol (Gambar 1c, d, e dan 3). Hasil analysis of varians (ANOVA) menunjukkan terdapat perbedaan jumlah fibroblas secara bermakna antara kelompok lidah buaya, povidone iodine dan kontrol seperti terlihat pada Tabel 1.

Jumlah Pembuluh Darah
Jumlah pembuluh darah pada penelitian
ini memperlihatkan jumlah rata-rata pada
kelompok povidone iodine lebih besar dibanding
kontrol, begitu pula pada kelompok lidah buaya
terlihat lebih banyak dibanding kontrol dan $s$ of

Tabel 1 Perbedaan Rata-rata Tebal Epitel, Jumlah Fibroblas, Jumlah Pembuluh Darah Antara Kelompok Kontrol, Lidah Buaya, dan Povidone lodine

\begin{tabular}{ccccc}
\hline \multirow{2}{*}{ Parameter } & \multicolumn{3}{c}{ Perlakuan } & \multirow{2}{*}{ Nontrol } \\
\cline { 2 - 4 } & $(\mathbf{n = 1 8})$ & $\begin{array}{c}\text { Lidah Buaya } \\
(\mathbf{n}=\mathbf{1 8})\end{array}$ & $\begin{array}{c}\text { Povidone lodine } \\
(\mathbf{n}=\mathbf{1 8})\end{array}$ & \\
\hline Tebal Epitel & $1,11(1,56)$ & $11,17(0,86)$ & $3,61(2,77)$ & $<0,001$ \\
Fibroblas & $26,72(6,63)$ & $82,50(13,11)$ & $18,61(7,13)$ & $<0,001$ \\
Pembuluh Darah & $3,06(2,44)$ & $11,67(1,41)$ & $4,56(2,64)$ & $<0,001$ \\
\hline
\end{tabular}



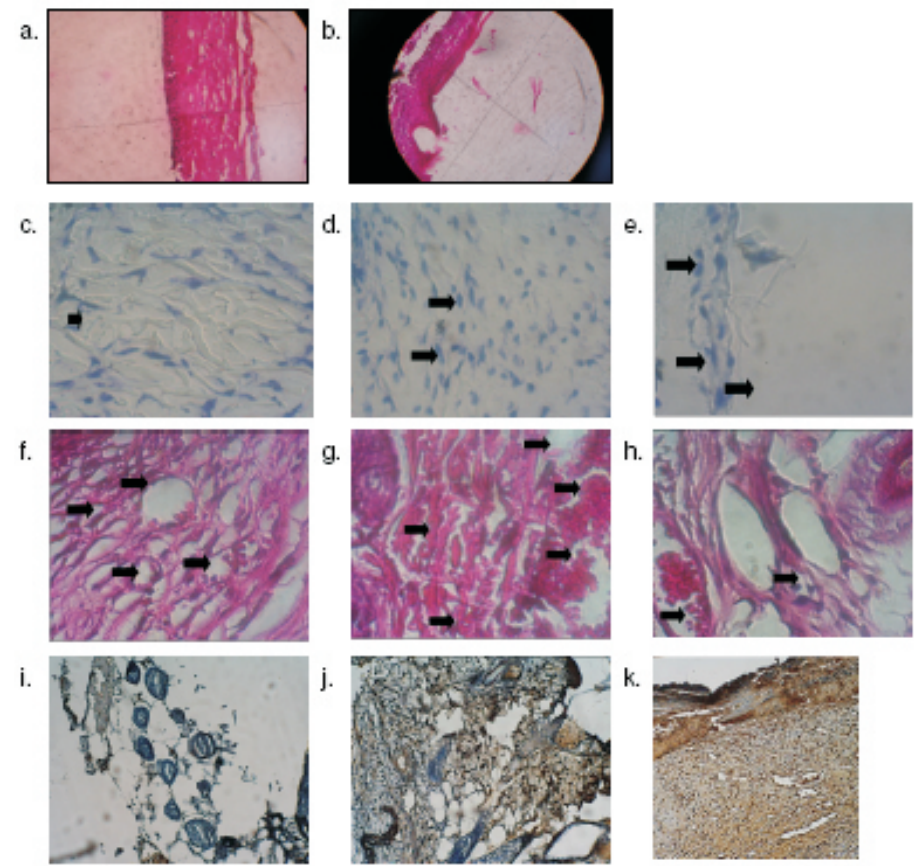

Gambar 1 (a) Gambaran tebal epitel yang tumbuh pada kulit mencit Kelompok Lidah Buaya pada hari kelima. (Hematoksilin - Eosin, 100x). (b) Gambaran tebal epitel yang tumbuh pada kulit mencit Kelompok Povidone lodine pada hari kelima (Hematoksilin - Eosin, 100x). (c) Gambaran fibroblas pada kulit mencit Kelompok Kontrol pada hari kelima. (Toluidin Blue, 400x). (d) Gambaran fibroblas pada kulit mencit Kelompok Lidah Buaya pada hari kelima. (Toluidin Blue, 400x). (e) Gambaran fibroblas pada kulit mencit Kelompok Povidone lodine pada hari kelima (Toluidin Blue, 400x). (f) Gambaran pembuluh darah pada kulit mencit Kelompok Kontrol pada hari kelima. (Hematoksilin eosin, 400x). (g) Gambaran pembuluh darah pada kulit mencit Kelompok Lidah Buaya pada hari kelima (Hematoksilin eosin, 400x). (h) Gambaran pembuluh darah pada kulit mencit Kelompok Povidone lodine pada hari kelima (Hematoksilin eosin, 400x). (i) Gambaran ekspresi VEGF (tidak terdapat VEGF yang terwarnai) pada kulit mencit Kelompok Kontrol pada hari kelima (Imunohistokimia VEGF A, 100x). (j) Gambaran ekspresi VEGF (positif sedang) pada kulit mencit Kelompok Povidone lodine pada hari kelima (Imunohistokimia VEGF A, 100x). (k) Gambaran ekspresi VEGF (positif kuat) pada kulit mencit Kelompok Lidah Buaya pada hari kelima (Imunohistokimia VEGFA, 100x)

perlakuan povidone iodine (Gambar 1f, $\mathrm{g}$, h dan 3). Data selanjutnya diuji dengan menggunakan uji analisis of varians (ANOVA) dengan hasil yang menunjukkan adanya perbedaan jumlah pembuluh darah secara bermakna antara kelompok lidah buaya, povidone iodine dan kontrol seperti terlihat pada Tabel 1.

\section{Ekspresi VEGF A}

Hasil pembacaan ekspresi VEGF A untuk masing-masing kelompok pada penelitian ini dapat dilihat pada Tabel 2. Hasil tersebut kemudian diuji dengan Chi square dengan hasil yang menunjukkan adanya perbedaan ekspresi VEGF A antara kelompok kontrol, kelompok lidah buaya, dan kelompok povidone iodine.

Ekpresi VEGF A antara kelompok lidah buaya dan kelompok povidone iodine menunjukkan hasil uji statistik dengan Chi Square yang menyatakan adanya perbedaan secara bermakna antara kelompok perlakuan lidah buaya dan kelompok povidone iodine dengan nilai p seperti pada Tabel 3 .

Pada Tabel 2 terlihat persentase sebesar $66,7 \%$ untuk positif kuat dan $33,3 \%$ tidak adanya ekspresi VEGF A yang terwarnai dengan pewarnaan imunohistokimia. Ekspresi VEGF A pada kelompok povidone iodine terdapat $66,7 \%$ memiliki nilai positif kuat, $16,7 \%$ positif sedang, dan $16,7 \%$ tidak terdapat VEGF A yang terwarnai dengan pewarnaan imunohistokimia. Sedangkan ekspresi VEGF A pada kelompok perlakuan lidah buaya seluruhnya memiliki nilai positif kuat $(100 \%)$. Hasil tersebut kemudian diuji dengan Chi square dengan hasil yang menunjukkan adanya perbedaan ekspresi VEGF antara kelompok kontrol, kelompok lidah buaya, dan kelompok povidone iodine dengan nilai $p 0,002(p \leq 0,05)$.

Tabel 3 menunjukkan hasil uji statistik dengan Chi square terdapat perbedaan ekspresi VEGF- $\alpha$ bermakna antara kelompok perlakuan lidah buaya dan kelompok povidone iodine dengan nilai $p 0,009(p \leq 0,05)$.

\section{PEMBAHASAN}

Pada hasil penelitian, rata-rata tebal epitel pada 

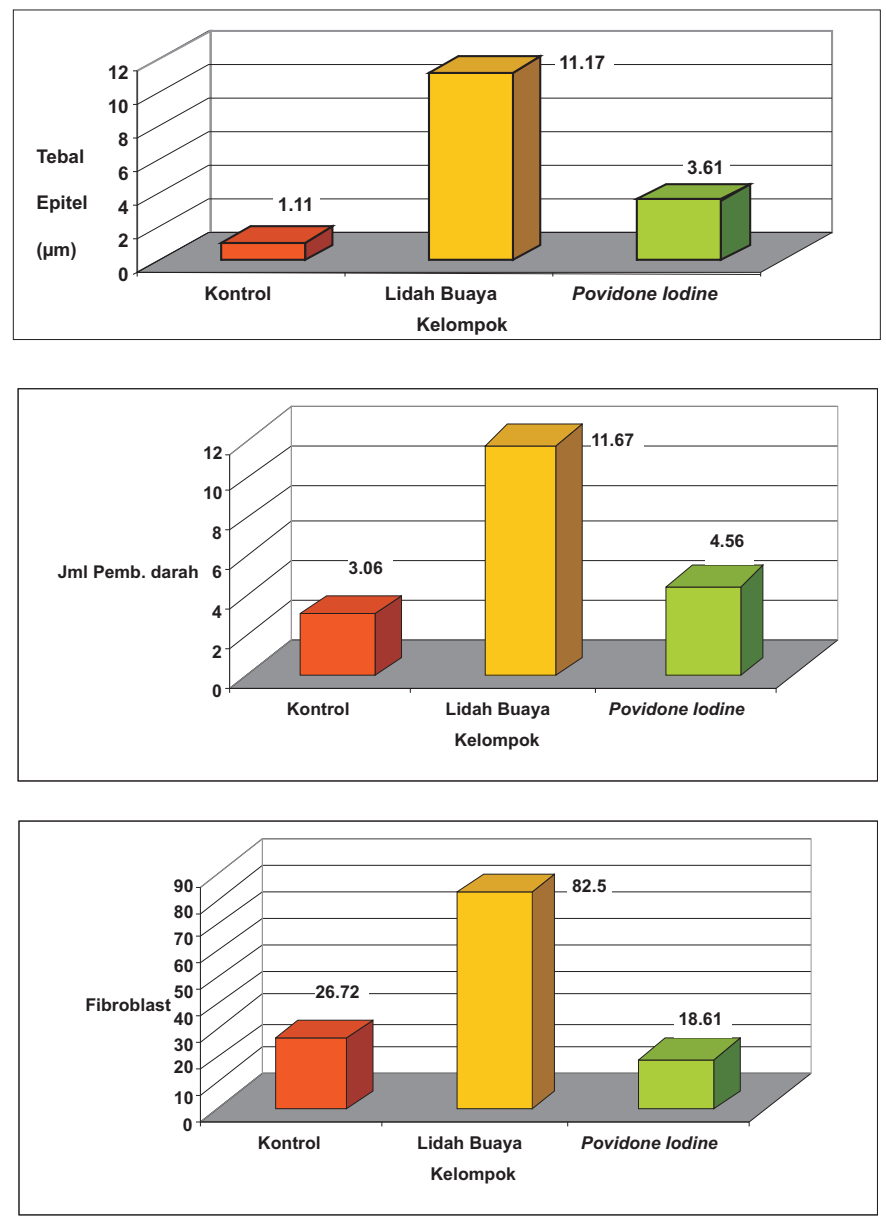

Gambar 2 Perbedaan Rata-rata Tebal Epitel, Jumlah Fibroblas dan Pembuluh Darah Antara Kelompok Kontrol, Lidah Buaya, dan Povidone lodine

Tabel 2 Perbedaan VEGF A Antara Kelompok Perlakuan Lidah Buaya, Kelompok Povidone lodine, dan Kelompok Kontrol

\begin{tabular}{ccccc}
\hline Variabel & \multicolumn{3}{c}{ VEGF A } & Nilai \\
& & & p \\
\cline { 2 - 4 } & Negatif & Positif Sedang & Positif Kuat & \\
\hline Perlakuan & & & & 0,002 \\
Kontrol & $6(33,3 \%)$ & $0(0,0 \%)$ & $12(66,7 \%)$ & \\
Lidah Buaya & $0(0,0 \%)$ & $0(0,0 \%)$ & $18(100,0 \%)$ & \\
Povidone iodine & $3(16,7 \%)$ & $3(16,7 \%)$ & $12(66,7 \%)$ & \\
\hline
\end{tabular}

Tabel 3 Perbedaan VEGF A Antara Kelompok Perlakuan Lidah Buaya dan Kelompok Povidone lodine

\begin{tabular}{ccccc}
\hline Variabel & \multicolumn{3}{c}{ VEGF A } & \multirow{2}{*}{ Nilai p } \\
\cline { 2 - 4 } & Negatif & Positif Sedang & Positif Kuat & \\
\hline Perlakuan & & & 0,009 \\
Lidah Buaya & $0(0,0 \%)$ & $0(0,0 \%)$ & $18(100,0 \%)$ & \\
Povidone iodine & $3(16,7 \%)$ & $3(16,7 \%)$ & $12(66,7 \%)$ & \\
\hline
\end{tabular}

kelompok lidah buaya lebih tebal dibandingkan kelompok kontrol dan povidone iodine. Meskipun bentuk povidone iodine yang cair memiliki keuntungan untuk mempercepat proses reepitelialisasi karena dapat memberikan suasana yang lembab pada luka sayat namun masih kurang menguntungkan dibandingkan dengan kandungan lidah buaya dalam hal mempercepat proses reepitelialisasi. Hal ini sesuai dengan penelitian Choi et al ${ }^{\rho}$ yang menyebutkan bahwa 
lidah buaya berefek stimulasi reepitelialisasi. Efek ini mungkin dikarenakan kandungan fraksi glikoprotein G1G1M1DI2 yang menstimulasi proliferasi keratinosit. Fraksi glikoprotein G1G1M1DI2 meningkatkan multiplikasi keratinosit, migrasi, faktor-faktor yang bersangkutan, dan pembentukan epidermis, yang berlanjut ke penyembuhan luka. ${ }^{4,9}$

Diketahui pula bahwa fraksi G1G1M1 DI2 meningkatkan sintesis DNA, begitu juga ekspresi reseptor epithelial growth factor (EGF). Reseptor EGF yang berikatan dengan ligan akan mentransmisikan signal proliferasi dari G1G1M1DI2. Adapun kemungkinan lain bahwa G1G1M1DI2 dapat mengaktivasi metabolisme umum dan meningkatkan aktivitas metabolik yang juga akan meningkatkan ekspresi reseptor EGF. Efek ini dapat mempercepat reepitelialisasi dengan meningkatnya multiplikasi serta migrasi keratinosit, dan meningkatkan kecepatan penutupan epidermal pada jaringan luka., ${ }^{9,10}$

Penelitian kali ini didapat jumlah rerata fibroblas pada kelompok lidah buaya lebih banyak dibandingkan kelompok kontrol dan povidone iodine. Hasil ini sesuai dengan teori yang menyebutkan bahwa lidah buaya dapat menstimulasi proliferasi fibroblas secara in vitro. Adanya peningkatan jumlah fibroblas pada kelompok yang diobati dengan lidah buaya mungkin disebabkan oleh aktivitas komponen manosa-6-fosfat yang dapat berikatan dengan reseptor IGF-2/manosa-6-fosfat reseptor yang terdapat pada permukaan sel fibroblas. Perikatan ini menyebabkan stimulasi fibroblas untuk berproliferasi, berdiferensiasi menjadi myofibroblas, ataupun menghasilkan kolagen dan protein matriks lain dalam jumlah besar. ${ }^{9,10}$

Mekanisme lain yang mungkin terjadi pada stimulasi fibroplasia adalah efek fraksi glikoprotein G1G1M1DI2 pada lidah buaya yang mempunyai efek stimulasi proliferasi sel dengan meningkatkan ekspresi reseptor EGF. Seperti yang telah diketahui sebelumnya bahwa EGF berperan penting dalam proliferasi sel, termasuk fibroblas. TGF- $\beta$ yang dihasilkan oleh platelet, makrofag, maupun neutrofil akan menginisiasi kaskade ini dengan mengaktivasi sel target (fibroblas) untuk memproduksi CTGF dan menjadi responsif terhadap CTGF. Apabila dalam lingkungan tersebut terdapat ko-mitogen (PDGF ataupun EGF), bersamaan dengan CTGF kedua faktor tersebut akan menstimulasi fibroblas untuk berproliferasi. Dengan kata lain, peningkatan ekspresi reseptor EGF oleh fraksi glikoprotein G1G1M1DI2 dapat meningkatkan proliferasi fibroblas. ${ }^{6,10-13}$

Pada penelitian ini juga didapatkan jumlah rata-rata fibroblas pada kelompok povidone iodine lebih rendah dibandingkan dengan kelompok kontrol. Hal ini sesuai dengan kesimpulan dari penelitian Balin dan Pratt $^{5}$ yang menyatakan bahwa povidone iodine dapat menghambat fibroblasia pada kultur sel in vitro.

Hasil pengamatan terhadap jumlah pembuluh darah dan ekspresi VEGF A menunjukkan jumlah rata-rata pembuluh darah dan ekspresi VEGF A lebih banyak pada kelompok lidah buaya dibandingkan dengan kontrol atau yang diberikan povidone iodine. Hal ini sejalan dengan penelitian Choi et $a l^{\beta}$ yang telah membuktikan efek angiogenik $ß$-sitosterol dari lidah buaya terhadap pembentukan pembuluh darah baru pada pembuluh darah otak mencit yang dirusak oleh keadaan iskemik. ßsitosterol dapat meningkatkan ekspresi protein yang esensial dalam angiogenesis, di antaranya VEGF, VEGF reseptor Flk-1, faktor von Willebrand, serta laminin. Adanya peningkatan pada ekspresi faktor-faktor ini dapat meningkatkan proliferasi dan migrasi sel-sel endotel, yang akhirnya dapat meningkatkan pembentukan pembuluh darah baru ..$^{10,14-16}$

Mekanisme lain ß-sitosterol dalam angiogenesis disebutkan dalam penelitian Moon $^{14}$. Pada penelitian ini senyawa ß-sitosterol menginduksi pembentukan pembuluh darah baru pada chorio allantoic membrane (CAM) pada embrio ayam. ß-sitosterol menstimulasi motilitas human umbilical vein endothelial cell (HUVEC) in vitro, yang akhirnya akan meningkatkan migrasi sel-sel tersebut. Efek angiogenik lidah buaya yang mungkin disebabkan oleh ßsitosterol ini ternyata dapat pula ditemukan pada proses penyembuhan luka. ${ }^{14,15}$

Jumlah rata-rata pembuluh darah dan ekspresi VEGF A pada kelompok povidone iodine lebih banyak dibandingkan dengan kelompok kontrol, hal ini dikarenakan kandungan molekul fosfolipid pada povidone iodine dapat mengkoordinasi migrasi sel endotel dan otot polos vaskular yang pada akhirnya dapat menginduksi angiogenesis. ${ }^{4,10,16}$

Efek lidah buaya terhadap penyembuhan luka juga mungkin dikarenakan oleh kandungan acemannan yang berperan sebagai agen poten yang mengaktivasi makrofag. Pada fase inflamasi makrofag berperan sebagai kunci regulasi perbaikan jaringan. Makrofag akan melepaskan sitokin dan faktor pertumbuhan (PDGF, TGF-a, TGF-ß, EGF VEGF), yang akan merekrut fibroblas, keratinosit, dan sel endotel untuk memperbaiki jaringan. Zat ini juga diduga berikatan dengan faktor-faktor pertumbuhan dan menstabilkan aktivitas faktor tersebut, serta melindungi dari panas dan degradasi enzim. ${ }^{6,10,17}$

Dengan demikian, dari hasil pengamatan yang telah dilakukan pada penelitian ini menunjukkan bahwa pemberian topikal gel lidah buaya terhadap luka sayat kulit mencit memiliki efek yang lebih menguntungkan dibanding dengan pemberian povidone iodine dalam hal menstimulasi reepitelialisasi, fibroblasia, dan 


\section{Ucapan Terimakasih}

Terimakasih dan penghargaan setinggitingginya penulis sampaikan pada dr. Bethy $\mathrm{S}$. Hernowo, $\mathrm{SpPA}(\mathrm{K}), \mathrm{PhD}$ yang telah membantu dalam pelaksanaan penelitian ini.

\section{DAFTAR PUSTAKA}

1. Cohen IK, Diegelmann RF, Yager DR, Wornum IL, Graham M, Crossland MC. Wound care and wound healing. Dalam: Schwartz SI, Spencer S, Fischer D, Galloway, penyunting. Principles of surgery. Edisi ke-7. New York: McGraw-Hill; 1999. h. 263-96.

2. Junquiera LC, Jose Carneiro. Basic histology: text and atlas. Edisi ke-11. New York: McGrawHill; 2005.

3. Wiksman LB, Solomonik I, Spira R, Tennenbaum T. Novel insights into wound healing Sequence of events. Toxicologic Pathol. 2007;35:767-79

4. Vogt PM PVP-iodine in hydrosome and hydrogel - a novel concept in wound therapy leads to enhanced epithelialization and reduced loss of skin grafts. Burns. 2006 Sep;32(6):698-705.

5. Balin AK, Pratt L. Dilute povidone-iodine solutions inhibit human skin fibroblas growth. Dermatol Surg. 2002 Mar;28(3):210-4.

6. Furnawathi I. Khasiat dan manfaat lidah buaya si tanaman ajaib. Edisi ke-7. Jakarta: Agro Media Pustaka; 2006.

7. Ni Y, Turner D, Yates KM, Tizard I. Isolation and characterization of structural components of Aloe vera L. leaf pulp. Int Immunopharmacol. 2004 Dec 20;4(14):1745-55.

8. Cole L, Heard C. Skin permeation enhancment potential of Aloe vera and and a proposed mechanism of action based upon size exlusion and pull effect. Intern $J$ Pharmaceutics. 2007;333:10-6.
9. Choi SW. The wound healing effect of a glycoprotein fraction isolated from Aloe vera. $\mathrm{Br}$ J Dermatol. 2001 Oct;145(4): 535-45.

10. Werner S, Grose R. Regulation of wound healing by growth factors and cytokines. Physiol Rev. 2002;83:835-70.

11. Amendt C, Mann A, Schirmacher P, Blessing M. Resistance of keratinocytes to TGF $\beta$ mediated growth restriction and apoptosis induction accelerates re-epithelialization in skin wounds. J Cell Sci. 2002, 115:2189-98.

12. Wang Z, Gao Z, Shi $Y$, Sun $Y$, Lin $Z$, Jiang $H$, et al. Inhibition of Smad3 expression decreases collagen synthesis in keloid disease fibroblasts. J Plastic, Reconstuctive \& Aesthetic Surgery. 2007; 60:1193-9.

13. Mori R, Shaw TJ, Martin P. Molecular mechanism linking wound inflamation and fibrosis: knockdown of osteopontin leads to rapit repair and reduced scarring. J Exp Med. 2008 Jan;205(1):43-51.

14. Moon EJ. A novel angiogenic factor derived from Aloe vera gel: $\beta$-sitosterol, a plant sterol. Korea. Department of Molecular Biology Pusan National University. Korea. 1999. [diunduh 10 Jun 2007]. Tersedia dari: URL: http://www.ncbi.nlm.nih.gov/pubmed/1451742 9?ordinalpos $\leq 11 \&$ itool $\leq$ EntrezSystem2.PEntr ez.Pubmed.Pubmed_ResultsPanel.Pubmed DefaultReportPanel.Pubmed_RVDocSum

15. Choi S, Kim KW, Choi JS, Han ST, Park YI, Lee SK, et al. Angiogenic activity of beta-sitosterol in the ischaemia reperfusion-damaged brain of Mongolian gerbil. Planta Med. 2002 Apr;68(4):330-5.

16. Roy H, Bhardwaj S, Herttuala S Y. Biology of vascular endothelial growth factors. FEBS Letters. 2006; 580: 2879-87.

17. Scrementi ME, Ferreira AM, Zender C, DiPietro LA. Site-spesific production of TGF-beta in oral mucosal and cutaneous wounds. Wound Repair Regen. 2008;16(1):80-6. 